\title{
Bunch and ratoon management for profitable production of high quality bananas (Musa acuminata, AAA) ${ }^{1,2}$
}

\author{
Héber Irizarry, ${ }^{3}$ Edmundo Rivera. and José A. Rodriguez"s
}

\begin{abstract}
Two long-term banana experiments were conducted to determine the effect of bunch bagging, removal of lower hands, and sucker management on fruit and bunch characteristics and fotal yield. Bunches covered with either Dursban-treated or untreated perforated polyethylene bags yielded $10,539 \mathrm{~kg} / \mathrm{ha}$ more than the uncovered ones during a 40 -month production period. Considering the price that quality bananas demand at the farm gate and the cost of bagging (materials and labor), this practice represents a net profit of $\$ 3,329.25 /$ ha. The removal of the three lower hands from the immature racemes significantly reduced bunch mean weight and total yield. However, both removal of lower hands and bunch bagging increased size of individual fruits in the distal hand, thus up-grading fruit quality. In addition, these practices also reduced the number of days required from bunch-shooting to harvest. The selection of a vigorous "sword" sucker soon after planting, combined with repeated pruning of other competing suckers produced the maximum yield of $183,744 \mathrm{~kg} / \mathrm{ha}$ during a 40 -month period.
\end{abstract}

\section{RESUMEN}

Manejo del racimo y los retoños para rendimientos rentables y frutos de alta calidad en guineos (Musa acuminata, AAA).

Se llevaran a cabo dos experimentos para estudiar los efectos de enfundar los racimos, remover las manos inferiores del racimo y seleccionar los hijuelos sobre las características del fruto, el racimo y en el rendimiento total. En ambos experimentos se obtuvieron datos por $\mathbf{4 0}$ meses. La producción media de los racimos cubiertos con bolsas de polietileno perforadas tratadas con el insecticida Dursban al $1 \%$ y $\sin$ tratar fue de $10,539 \mathrm{~kg} / \mathrm{ha}$ más que en los racimos sin enfundar. Considerando el precio que se paga por el guineo de alta calidad empacado en la finca y el costo de cubrir el racimo (materiales y mano de obra), el uso de esta práctica resulta en una ganancia nefa de $\$ 3,329.25 /$ ha. La remoción de las fres manos inferiores del racimo inmaduro redujo significativamente el peso medio final de los

Manuscript submitted to Editorial Board 18 October 1991.

2This paper covers work carried out cooperatively between the Agricultural Research Service-USDA and the Agricultural Experiment Station, University of Puerto Rico (UPRAES), Río Piedras, Puerto Rico. Rico.

"Research Horticulturist, Agricultural Rewarch Service-USDA, Mayaguez, Puerto

${ }^{4}$ Agronomist, Agricultural Research Service-USDA, Mayaguez, Puerto Rico.

"Associate Agronomist, Department of Agronomy and Soils.

"Trade names in this publication are used only to provide specific information. Mention of a trade name does not constitute a warranty of materials by the USDA/ARS or the UPR-AES, nor is this mention a statement of preference over other materials. 
racimos y el rendimiento total. Sin embargo, el eliminar manos y el enfundar los racimos aumentaron substancialmente el tamaño y el peso de las frutas individuales en la mano disfal, con lo que mejoró la calidad de los frutos. Ambas prácticas, además, acortaron el tiempo entre la floración y la cosecha. La selección de un hijuelo de "lanza" vigoroso inmediatamente después de la siembra seguido de la poda continua de otros hijuelos competidores produjo el mayor rendimiento equivalente a $183,744 \mathrm{~kg} / \mathrm{ha}$ de frutos.

\section{INTRODUCTION}

Local banana production is estimated at 85,000 metric tons per year with a farm gate value of $\$ 9$ million (9). About $22 \%$ of the crop is sold as ripe fresh fruits (4).

Most of the production originates from the tall. Montecristo cultivar growing in the mountain region intercropped with coffee and without proper management. Under these conditions, yields are low, quality is poor, and profits are negligible. The availability of high yielding dwarf banana cultivars (7) offer's growers the opportunity to implement appropriate bunch and sucker management practices for the production of quality fruits that conform to modern market requirements and generate acceptable profits.

Banana bagging has been found to increase bunch weight by 10 to $15 \%(3,12)$, to reduce the time from bunch-shooting to harvest, and to improve grading of fruits by protecting against fungi and insect damage and blemishes $(8,10)$. The increase in bunch weight is attributed to a rise in temperature and humidity inside the plastic bag.

The removal of the male flower bud and lower hands from the immature bunch has been shown to increase individual fruit size and weight at the expense of reducing total bunch weight $(1,5)$. This practice, however, is considered justifiable by Calvo and Soto (2), because it up-grades fruit quality and shortens the interval from bunch-shooting to harvest.

The timed desuckering of the banana plant is another field practice that can affect long-term production (11). Proper sucker management permits control of the number of production units in successive ratoons.

This paper reports the effects of bunch bagging, removal of lower hands, and ratoon-sucker selection on yield and fruit quality of the 'Grand Nain' banana.

\section{MATERIALS AND METHODS}

Two experiments were established at the Corozal substation and on a private farm in the municipality of Lares from October and December 1983 through April 1987.

The Lares experiment was planted on Mr. Luis M. Elizalde's farm, at an elevation of $450 \mathrm{~m}$. No weather data were recorded at this location; however, in a normal year, rainfall is more abundant than at the Corozal 
substation. The soil is a Humatas clay (Typic Tropohumults, clayey, kaolinitic, isohyperthermic). The upper $30 \mathrm{~cm}$ of soil contained $6.3 \mathrm{mg} / \mathrm{kg}$ of available phosphorus (Bray Method II), and had an exchangeable base capacity of $7.1 \mathrm{cmol}(+) / \mathrm{kg}$ of soil. The initial soil pH was 4.2 and limestone was surface-applied at the rate of $6.7 \mathrm{t} / \mathrm{ha}$.

The Corozal substation is at an elevation of $200 \mathrm{~m}$. Mean monthly rainfall was $174.8 \mathrm{~mm}$, and pan evaporation $122.7 \mathrm{~mm}$. However, evaporation exceeded rainfall by $25 \%$ during January, February, March, June and July. The average monthly minimum and maximum temperatures were 19.5 and $29.5^{\circ} \mathrm{C}$, respectively, with a variation of $1.5^{\circ} \mathrm{C}$. The soil is a Corozal clay (Aquic Tropudults, clayey, mixed, isohyperthermic).

The upper $30 \mathrm{~cm}$ of soil contained $3.3 \mathrm{mg} / \mathrm{kg}$ of available phosphorus, and had an exchangeable base capacity of $10.4 \mathrm{cmol}(+) / \mathrm{kg}$ of soil. During land preparation, limestone was incorporated at the rate of $4.5 \mathrm{t} / \mathrm{ha}$ to increase the $\mathrm{pH}$ to about 5.2 .

In both experiments suckers of 'Grand Nain' weighing about $2 \mathrm{~kg}$ each were planted at 1.8 by $1.8 \mathrm{~m}$. The plant crop received $3,300 \mathrm{~kg} / \mathrm{ha}$ of a 10-5-20-3 (N, $\mathrm{P}_{2} \mathrm{O}_{5}, \mathrm{~K}_{2} \mathrm{O}$ and $\left.\mathrm{MgO}\right)$ fertilizer supplemented with 25.4 $\mathrm{kg} / \mathrm{t}$ of a fritted minor element mixture. The fertilizer was divided into equal applications 2,5,8 and 11 months after planting. Thereafter, the ratoon crops were fertilized with $750 \mathrm{~kg} / \mathrm{ha}$ every 3 months.

The experiments were maintained free of weeds with postemergence applications of glyphosate (Round-up) ${ }^{6}$ at the rate of $1.5 \% \mathrm{v} / \mathrm{v}$.

Yellow Sigatoka (Mycosphaerella musicola), nematodes, and the corm weevil (Cosmopolites sordidus) were controlled according to UPRAES recommendations (6).

At the Lares experiment three bunch bagging and three dehanding treatments were arranged in a split-plot design with six replications of 12 plants per sub-plot. The main treatments consisted of covering the immature bunches with either insecticide-treated or untreated polyethylene bags or leaving the bunches uncovered. The bags were made of blue-perforated polyethylene film $0.05 \mathrm{~mm}$ in thickness. The insecticide-treated bags were factory impregnated with Dursban at $1 \%$. In the subtreatments the immature bunches (fig. 1) were subjected to the removal of the male flower bud with either one, two or three lower hands. All treatments were applied 3 weeks after bunch-shooting.

A desuckering program was implemented throughout the experiment. It consisted of maintaining in each stump the "mother" plant plus two suckers, the latter representing the "daughter" and "grandaughter" plants.

At the Corozal experiment four ratoon-sucker management treatments were evaluated in a randomized complete block design with six replications of 15 plants per plot. In the plant crop, the treatments were as follows: 1 a vigorous "sword" sucker selected soon after planting and 




Fig.2-Banana stump showing three production units, the "mother", "daughter" and "granddaughter" plants. 
J.Agric. Univ. P.R. voL. 76, NO. 3-4, JULY/OCTOBER, 1992125

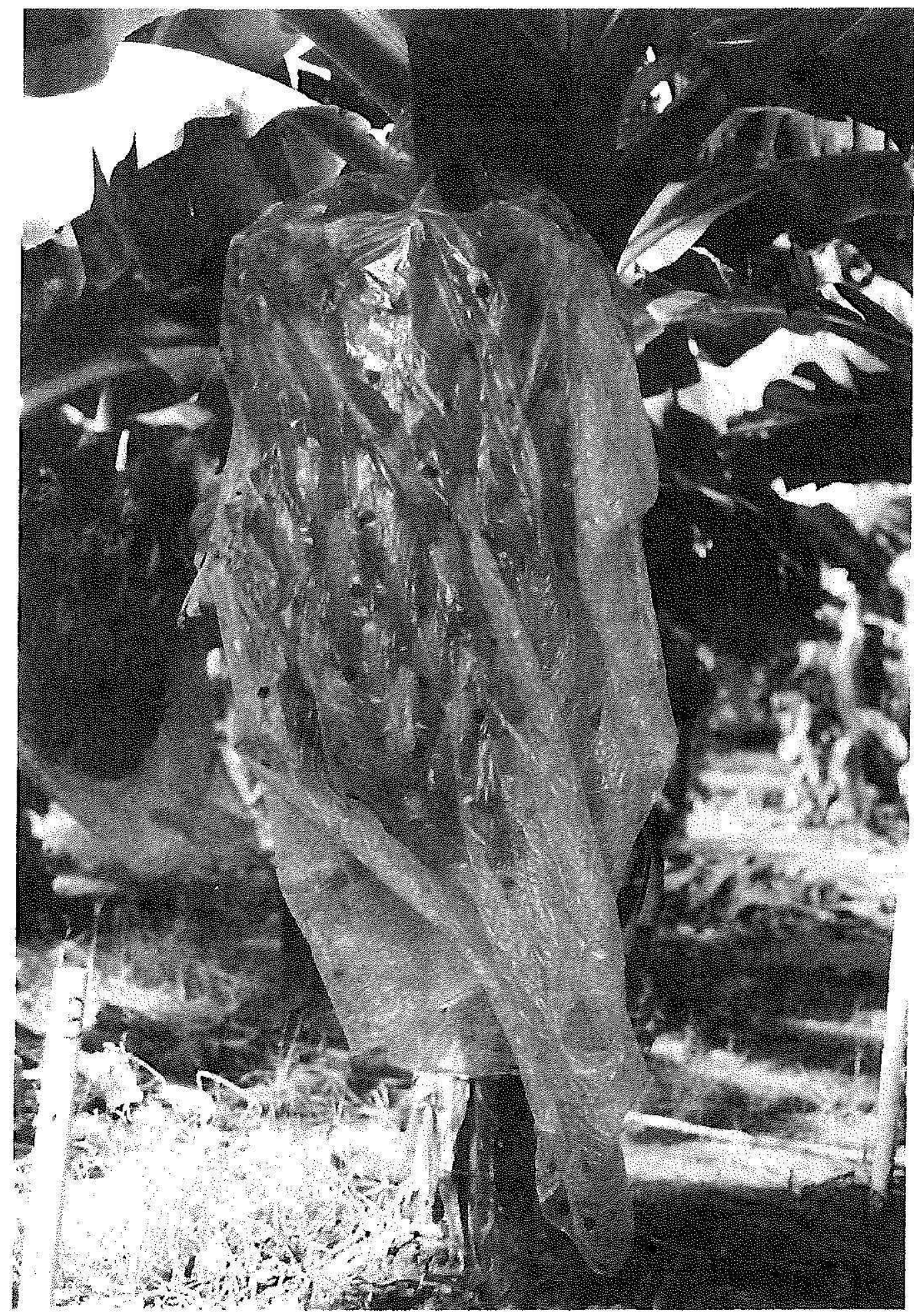

FIG. 3-Mature-gxeen banana bunch covered with a perforated polyethylene bag. 
TABLE 1.-Effect of bagging on bunch weight, total yield and size of fruits in the distal hand of the banana raceme intensively managed during a 40 -month period at Lares, Puerto Rico

\begin{tabular}{|c|c|c|c|c|c|c|c|}
\hline \multirow[b]{2}{*}{ Bagging treatment } & \multirow{2}{*}{$\frac{\text { Plant crop }}{\text { Bunch weight }}$} & \multirow{2}{*}{$\frac{\text { Ratoon crops }}{\text { Bunch weight }}$} & \multicolumn{2}{|c|}{ Combined plant and ratoon crops } & \multicolumn{3}{|c|}{ Fruit measurements } \\
\hline & & & Bunch weight & Total yield & Length & Diameter & Weight \\
\hline Bunch coverert with treated & $\mathrm{kg}$ & $\mathrm{kg}$ & $\mathrm{kg}$ & $\mathrm{kg} / \mathrm{ha}$ & $\mathrm{cm}$ & $\mathrm{cm}$ & $\mathrm{g}$ \\
\hline & $20.1 a^{2}$ & $24.5 \mathrm{a}$ & $22.3 \mathrm{a}$ & $150,545.5 \mathrm{a}$ & $17.1 \mathrm{a}$ & $3.4 a$ & 120.1a \\
\hline polyethylene bags & $19.8 \mathrm{a}$ & $24.3 \mathrm{a}$ & $22.1 \mathrm{a}$ & $149,405.6 \mathrm{a}$ & 17.02 & $3.4 a$ & $118.7 \mathrm{a}$ \\
\hline Bunch uncovered & $18.3 \mathrm{~b}$ & $22.8 a$ & $20.6 \mathrm{~b}$ & $139,436.8 b$ & $16.3 \mathrm{~b}$ & $3.2 \mathrm{~b}$ & $110.7 \mathrm{~b}$ \\
\hline
\end{tabular}

'Means followed by the same letters in each column do not differ significantly at $\mathrm{P}=0.05$ probability level. 
TABLE 2.--Effect of removal of lower hands on bunch characteristics, total yield and size of fruits in the distal hand of the banana raceme intensively managed during a $40-$ month period at Lares, Puerto Rico

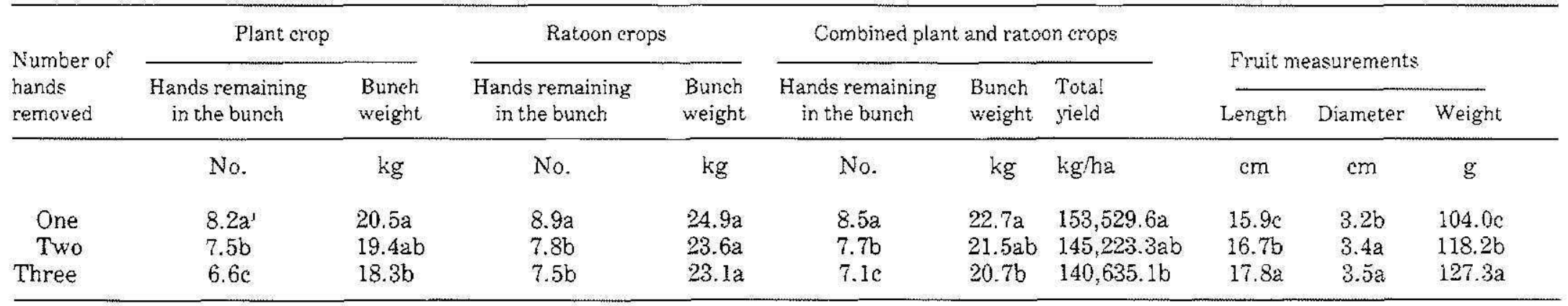

${ }^{1}$ Means followed by the same letters in each column do not differ significantly at $\mathrm{P}=0.05$ probability level. 
TABLE 3.-Effect of ratoon-sucker selection on bunch weight and total yield of bananas intensively managed during a 40 -month period at Corozal, Puerto Rico

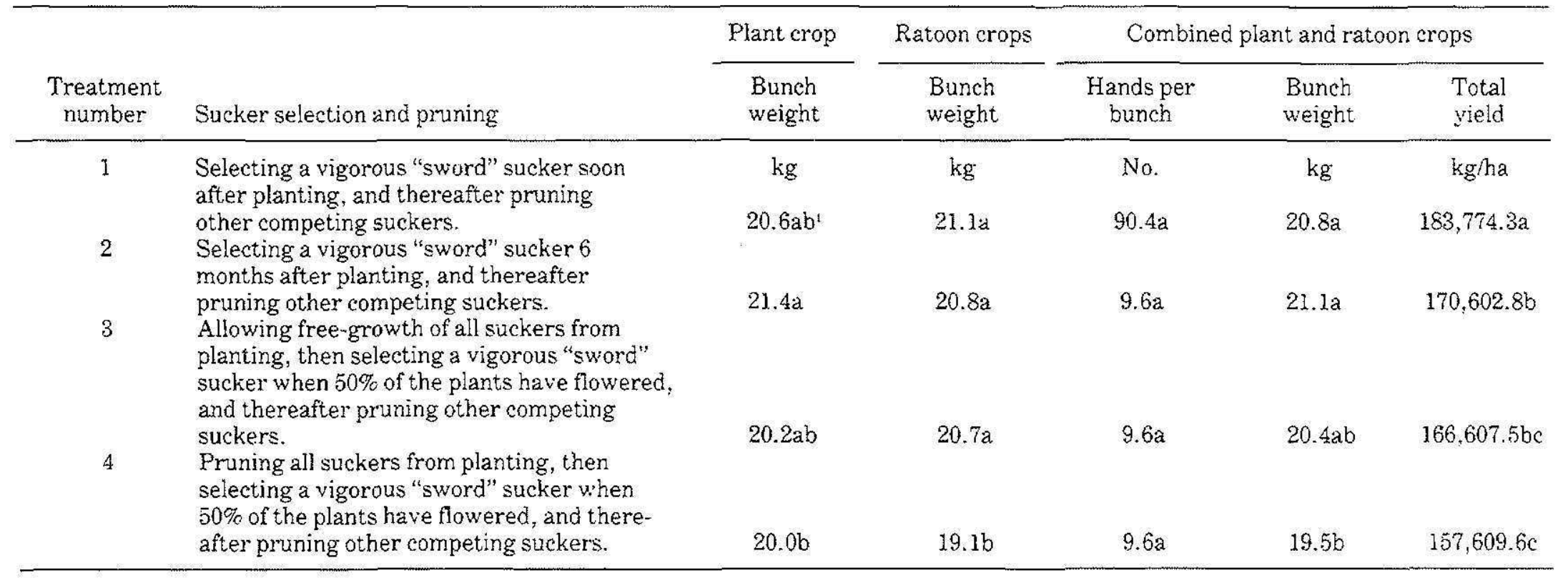

Means followed by the same letters in each column do not differ significantly at $P=0.05$ probability level. 
days from bunch-shooting to harvest, while the uncovered ones required 112 days to reach the fruit harvest criterion of $3 / 4$ full.

The removal of one to three lower hands from the immature racemes progressively reduced bunch size and weight, and total yield in all crops (table 2). Except for bunch weight in the ratoon crops, the effect was always significant with the removal of three hands. However, individual fruit size and weight in the distal hand were appreciably increased at the expense of reducing total yield by 5.4 to $8.4 \%$ (table 2). Racemes trimmed by two and three hands averaged 109 days from bunch-shooting to harvest, whereas fruits in racemes with only one hand removed took 114 days to reach a marketable grade.

Both bunch bagging and removal of lower hands improved banana grading, but fruits in the distal hand were smaller than those reported for the Grand Nain cultivar in Costa Rica. According to Soto (11), individual fruit length can be affected by an excess or deficit of soil moisture during the first 30 to 40 days after bunch-shooting.

\section{Corozal experiment}

The peak plant-crop harvest at Corozal occurred 13 months after planting. Except for treatment 1, other ratoon treatments averaged 2.7 marketable bunches per stump during a 40-month production period. The selection of a vigorous "sword" sucker soon after planting (treatment 1), combined thereafter with the pruning of other competing suckers produced about 2.9 marketable bunches per stump with a maximum yield of $183,744 \mathrm{~kg} / \mathrm{ha}$ (table 3 ). Since bunch weight was similar for treatments 1 through 3 in all crops, we conclude that the increase in total yield detected in treatment 1 (early "sword" sucker selection) was mainly the result of $20 \%$ more bunches being harvested during a 40 -month production period. Pruning of all suckers from planting and then delaying the selection of a ratoon sucker until flowering (treatment 4) significantly reduced bunch weight and total yield (table 3 ).

\section{LITERATURE CITED}

1. Boncanto, A. A., 1969 Effects of reducing the number of hands in a bunch of Lacatan banana. Philipp. I. Plant Ind. 32(2-4): 243-51.

2. Caivo, J. and $M$. Soto, 1985. Effects of dehanding in banana fruit quality in the "Great Dwarf" cultivar, Musa AAA Cavendish. Proc. ACORBA'T, 7th Meet. (Sept. 23-27), San José, Costa Riea 311-15.

3. Cann, H. J, 1965. Banana growing - plantation practices. J Agric. Gaz Nw. S. Wales 76(11): $672-78$.

4. Cortés, M. and J. García, 1990. La Empresa de Guineos: Plantas de Maduración. Bol. 286, Esta. Exp. Agric. Univ. P.R.

5. Hasselback, O. E. and J, Idoe, 1973. Dehanding of bananas in Surinam. J. Surname Landbow 2(3): 127-32.

6. Irizarry, H. and R. Montalvo-Zapata, 1986. Conjunto Tecnológico para la Producción de Plátanos y Guineos. Publ. 97, $2^{\text {do }}$ ed. Esta. Exp. Agríc. Univ. P.R. 
7. - E. Rivera, I. Beauchamp de Caloni and R. Guadalupe, 1989. Performance of elite banana (Musa actuminata AAA) cultivars growm in four locations of Puerto Rico. J. Agric. Univ. P.R. 73(3): 209-21.

8. Johnson, S., 1975. Fundas de polietileno con insecticida protege racimo de banano. $L a$ Hacienda (USA) 70(3):22-25.

9. Ortiz-López, J., 1991. Plátanos y guineos: Situación y perspectivas - Empresas agricolas de Puerto Rico en 1988-89. Esta. Exp. Agrie. Univ. P.R.

10. Perumal, A. and A. V. Adam, 1968. Bagging of Giant Cavendish banana stems in Honduras, I - Effect on number of days from flower emergence to fruit harvest. Trop. Agric. (Trinidad) 45(2): 109-12.

11. Soto, M., 1985. Bananos: Cultivo y comercialización. Comp. Agric. Ganadera Cariari, San José, Costa Rica.

12. Turner, D. W. and L. E. Rippon, 1973. Effect of bunch covers on fruit growth and maturity in bananas. Trop. Agric. (T'rinidad) 50(3): 235-40. 